heat of London sensibly affects Greenwich, mostly by raising the temperature of the air in winter and at night, when it might be expected to do so with the greatest effect; and that the temperature at Greenwich by day in summer is depressed by the smoky atmosphere hindering the transmission of the sun's rays when they are most potent.

Croydon, April 24

H. S. EATON

\section{Ancient Characters at Cissbury}

Two years ago some marks were discovered at the entrances of galleries in one of the pits at Cissbury, which appeared to have been scratched on the chalk with a flint instrument. They were suspiciously like figures or masons' marks, but yet had all the tints of age, and resembled more or less early letters. ${ }^{1}$ The little woodcuts $/ C, \perp$ represent the forms with sufficient exactness. Other marks found shortly afterwards in a second pit were thought to be merely a trellis pattern. In attempting to cut them out of the rock, the chalk was broken into fragments, but fortunately rubbings had been previously taken.

The doubt as to the genuineness of the above marks was removed by the further discovery, in September, 1875 , of a third set (again at the entrance of a gallery) in another pit at Cissbury Camp. They were arranged in two lines, the lower one presenting all the appearance of an inscription. A number of detached blocks, with distinctive marks upon them, were found in this pit amongst the rubble with which it was filled. One of these blocks, which was discovered about five feet below the surface, had four definite marks scratched upon it at even distances.

Up to the time that this third pit was opened no distinctive marks had been met with, except those above-mentioned, though tbere were many thousand accidental pick-marks on the walls and bose chalk.

T have nory the satisfaction of mentioning that upon examining witn more care the marks found in the second pit, the diagonal scratches of the trellis prove to be eight branching characters of a peculiar form. The vertical scores which cross them turn out to be later additions, cut with a finer tool than the serrated flint that has left its mark on the more superficial and broader lines of the characters beneath. In the following woodcut the vertical lines are not shown, and the rune-like forms are placed slightly further apart than is ac: ually the case ; the characters themselves, however, are facsimiles ${ }^{2}:-$

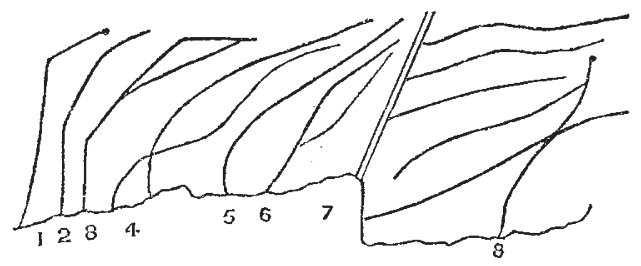

Tracings and photographs have been submitted to Professors Sayce and Rhr̈s, and also to Dr. Haigh and other palreographists, who all consider the marks to be characters, though unatsle at present to give an opinion as to their date. But several on the detached blocks found near the surface, it is thought, may possibly be Anglo-Saxon.

Some of your correspondents may perhaps be able to say whether similar forms have been met with elsewhere. Can it be that the branching characters are examples of the symbols alluded to in the traditions of the Bards?

I may mention that Dr. Haigh thinks that the Celts had writing distinct from and earlier than the Oghams; and he has noticed on the stones of a sepulchral chamber at Keryaval, in Brittany, signs very like letters.

J. PARK HARRISON

\section{The Rocks of Charnwood Forest}

IT has been a matter of regret to geologists that Mr. Plant has not published in some accessible form his stores of knowledge on Charnwood. We cannot tell how far our facts may be new to him, but we believe that we have been able to make considerable corrections in and additions to all contained in Jukes, Ansted, Coleman, or the Survey Memoir.

I Foum. Antturopol. Inst., No. 18, p. 265.

2 The last character, on the right of the inscription, has been corrected by lengthening the upper stroke. In the rubbing it was accidentally cle-
iached from the cross-lines.
We are glad to find Mr. Plant supporting us on the intrusive character of the syenites. But the question can hardly be regarded as previously settled. Mr. Coleman leaned to the idea of their priority to the stratified rocks, Prof. Jukes to their being contemporaneous, and Prof. Ansted to their being metamorphic. When in Nature (vol. xv. p. 97) Prof. Green suggested the first of these views no one adduced any proof to the contrary. Of all that $\mathrm{Mr}$. Plant says we were well aware, but could not regard the evidence as conclusive. Our opinion is founded on the examination of actual contacts between syenite and sedimentary rock; a thing which so far as we know has not previously been described.

We are well acquainted with the very curious "altar stones" which are doubtless of volcanic origin, but these and the rocks of Bardon no more prove the Markfield syenite to be intrusive, than the ashes and breccias of the Borrowdale series prove the intrusive character of the Wastwater granite. Further, we cannot admit any cornection between the Bardon "greenstones" and the Markfield syenite.
St. John's College, Cambridge, April 28
E. HILI

\section{Yellow Crocuses}

SEVERAL years ago I observed that snowdrops which I had introduced into my garden were destroyed by poultry getting in among them at the hungry season when these are in blussom. $I$ recollect placing a bantam cock in the garden, and observed that he pecked bastily at a few of the blossoms, and then left off. I then tore up pieces of writing-paper and spread them over the newly turned-up soil. These were hastily visited and as hastily dropped by a few of the pouliry. Next I procured some Indian corn, and scattered it among the poultry for the first time. A few hens tried to swallow a grain here and there, but left the most of them. It required two or three days' experience to get them to feed on the Indian corn, and a. very short time taught them to exclude snowlrop blossoms from their bil of fare. May not the case of the crocuses mentioned by Mr. Renshaw be explained as similar to that of schoolboys, who eagerly try a bright unknown berry and soon leave off when it is unpalatable? At least so I explained the fact of my snowdrops being more fiercely attacked on their first appearance in the garden than ever they have been since.

Our glen in a few weeks will be made beautiful by the biossoms of the bird-cherry, which grows plentifully on the margin of the streams and the waysides, attaining much laroer dimensions than those given by $M r$. Bentham in his "Handbook of British Flora," many of the trees being twenty feet high. The caterpillar of the pale spotted ermine moth feeds so eagerly on its leaves that I have, in some summers, seen the trees reduced to ugly skeletons by the middle or end of July. In autumn the beautiful red berries of the Guelder-rose adorn our thickets, but if "fruit has become beautiful so as to point it out to birds for the dissemination of the seed," we do not seem to have the birds which care for these berries, as only three weeks ago I pulled some fine clusters from a bush growing in a sheltered nook.

Tynron, Dumfriesshire, April 2r JAMES SHAW

INCLOSED is a letter that I had from my friend; Dr. Grierson, Dumfriesshire, a month ago, complaining of a pair of ducks that had gobbled up almost every one of his yellow crocuses, and only the yellow ones. I am further informed by Mr. John Young, Hunterian Museum, Glasgow, that the habit of the sparrows taking the yellow crocuses without touching the blue or striped has been long known to him. DAVID ROBERTSON

\section{The Ship.Worm}

Teredo nuvalis certainly is able to endure a long continuance of fresh water. At the town of Brisbane (Qreensland), piles, Sc., are sheathed with "Muniz metal" to prevent its attacks. The river is subject to long-continued freshes. I remember one which lasted at least ten days, and during that time ocean-going steamers could not ascend to the town, the flood was so powerful. Brisbane is situated far below the extreme salt-water flood, but whenever there is a fresh in the river, of even small amount, the water at that town is (according to my recollection) rather more fresh than salt at the end of each ebb tide.

I never saw Teredo there, but I took its existence for granted, from the fact that piles, \&c., were protected with metal, and the 